\title{
Children in Roma families
}

\section{Denisa Selická}

\begin{abstract}
Romany people and families have an irreplaceable role in their children's education. We cannot replace this effectively with any other social institution that might possibly aim to take on this role. In the paper we present the opinions of experts. The focus is on the position of the Roma child in the family and the related specific features of this.
\end{abstract}

Key words: Roma family, pupil, child's role.

\section{Děti v romských rodinách}

\section{Abstrakt}

Romové a romské rodiny mají nezastupitelnou roli ve vzdělávání svých dětí. Nemůžeme to účinně nahradit žádnou jinou sociální institucí, která by se snažila tuto roli převzít. $\checkmark$ príspěvku prezentujeme názory odborníků. Důraz je kladen na postavení romského dítěte $v$ rodině a jeho specifické rysy.

Klíčová slova: romská rodina, žák, role dítěte.

DOI: 10.5507/epd.2019.012 


\section{Introduction}

Families, whether Roma or non-Roma, play an irreplaceable role in the upbringing of children. We cannot replace them with any other social institution that could take on their role in an acceptable way (Pocklan, 1992). Each family designs an original style of education, which results from mutual interactions. The quality of the bond between the child and the mother, and later between the child and the father and other family members, represents a key factor in the personal development of the child (Potočárová, 2008). Children are highly valued in Roma families. For centuries, the most important thing in Roma settlements was that children did not go hungry and that they were healthy and happy. Mothers were and are especially concerned with their first child who, when they grow up, cares for their younger siblings. To this day, grandparents also have an important role to play in raising children. Girls were brought up so that at the age of 14-15 they are ready to find a partner. The father took charge of boys' education from the age of five or six. Based on their age and physical fitness, they helped with male-allocated labour tasks. Gradually, fathers introduced their sons to their own craft or employment. In the families of musicians, it was common that 12-13-year-old boys played in a band together with their fathers and uncles. The oldest brother - baro phral - had extensive educational responsibilities towards his younger siblings. The eldest brother had a great responsibility towards his sisters, especially at the time of their maturity, and guarded their honour. The youngest son usually remained in the parental home and looked after his parents until their death. In the family - familia - children acquire good behaviour and romipen - Roma traditions and ethics (Mann, 1992). From the point of view of the child's security and safety, it is essential if a child witnesses quarrels and misunderstandings between parents as a way of observing the handling of problematic family situations. Critical situations in families can affect the behaviour and well-being of the child, which often influences their way of handling these situations. Relationships between parents, siblings, parents and children are among the most natural of human relationships. On the one hand, they may be the cause of difficulties, misunderstandings, and problems, but they can also determine family education (Hamarová, Holkovič, 1987).

According to Matulay (2000, pp. 45-46), the Roma family is characterized by the following:

- Education is not individualistic but collectivist.

- Everything is addressed collectively.

- The first law in the education of a child is its freedom.

- The child is not required to work hard in order to complete his/her school duties.

- The family protects the child, it is its refuge, but also a barrier that cannot be crossed.

- The family transfers Roma values to the child. 
The social environment of the family, the special arrangement of relationships and family ties, fulfils similar functions to that of the uterus at the biological level. A family, with its typical ties, interactions, upbringing, maternal and paternal roles, sibling roles, and extended roles (e.g. those of the grandparents) creates an evolving human being, a "social uterus" and "social placenta" which guarantees nutrition and energy and enables growth and advancement. Lifelong development of the person will be accompanied by the continuous creation of boundaries and a defined space in which, according to the characteristics of the child's age, specific developmental tasks will be fulfilled (Potočárová, 2008). Every child should be offered equal educational conditions, regardless of their origin. Education policy is regarded as the main tool for prevention of intergenerational poverty. Education is considered of high importance because generally speaking, the higher the level of education, the lower the risk of poverty (Šarvajcová, 2015, p. 27).

Relationships between parents and children evolve. Family is predominantly associated with marriage, although single mothers and children, or unwedded partners and children, which are more frequent models in Roma families, are also considered families. When a child is born, the bond between the man and the woman is relaxed, because adults transfer some of their emotions to the child. Relationships between the parents change again after children leave the family, but relationships between parents and children are also subject to change. With age, the unilateral influence of parents on children who show obedience to their parents when it is valued the most, is also mitigated. By increasing the active participation of children in family affairs and by expanding their contacts outside the family, subordination is alleviated. The more responsibilities the children take on, the less their parents have to participate in their own life decisions, so gradually it is the parents who in old age are helpless, need support, advice, and the certainty that someone loves them and will look after them (Hamarová, Holkovič, 1987).

It is important to remember, however, that we have recently encountered a serious social phenomenon in which the relationships between people in society and in families are changing very quickly. In particular, the family is changing its function and structure at such a rate that there are fears that as a social institution, it might cease to fulfil its mission. Many families are suffering from a crisis that has multiple causes which are spiritual, economic, social and cultural in nature. Families with more children are at a further disadvantage. The functioning of the family is determined by the mutual relations of its members: partners, siblings and intergenerational relationships. If these fail, there is internal tension in the family resulting in its destabilization, which may have severe consequences (Sumec, 2005).

Viková's research (1996) shows that relationships in Roma families are still hierarchical. Roles among siblings are determined by gender and birth order. Parents do not treat all their children in the same way. Each role brings different duties and personal 
responsibility. Respect for mothers and grandparents is typical for Roma families; for example, in the case of an argument between a mother-in-law and a daughter-in-law, the man always takes his mother's side.

Liégeois (1995) also notes that younger and older children live in the close-knit security of their community, which offers protection from the unknown and a future. If relationships within the environment are negative, limited, or a source of dissatisfaction, the family's role is all the more important. The social role of the Roma family is therefore at the forefront and at the same time it compensates for the absence of relationships of a different nature (school, work, relationships with the wider population, etc.).

\section{Picture 1}

In the pool

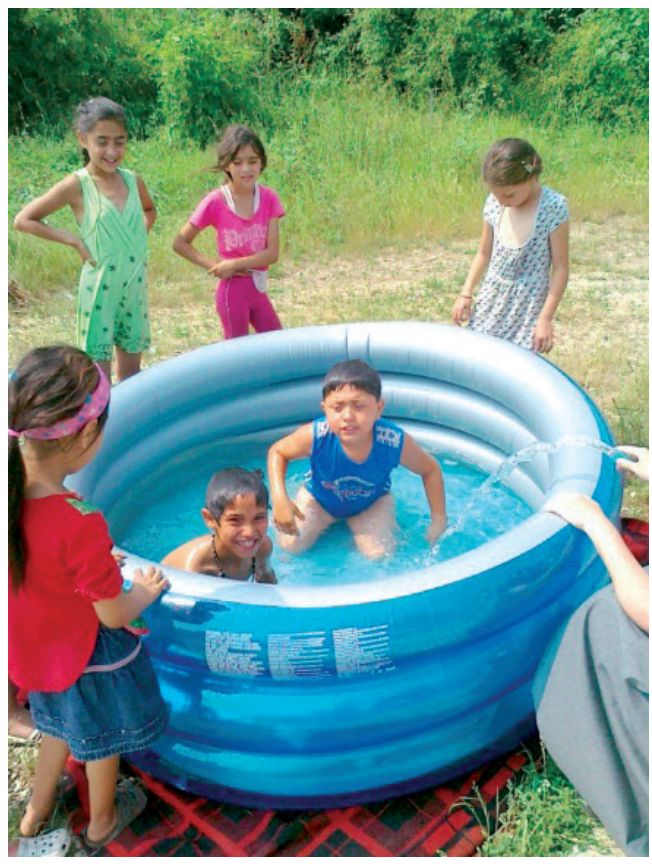

Roma children are brought up in such a way that they are not afraid to express their thoughts and do not wait for permission to speak. "Spoken taboos" are quite different in Roma families. For example, even though chastity in terms of wearing proper or modest clothing is usually expected more than for the wider population, taboo topics do not include sex. Roma families discuss prison, theft, violence or sexual deviance without 
inhibition. Roma children hear everything and are actively engaged in debate. They also discuss the problems of other people (Sekyt, 1998).

Small children are taken care of for a long time and they are not led towards independence. Boys are introduced to autonomy and self-sufficiency much less, because everything is done by their mothers or older sisters. On the other hand, Balabánová (2000) claims that children are given independence from an early age, and parents treat them as adults and equal partners quite early on. Perhaps she is referring to the fact that parents, especially mothers, care for the youngest child in the family, and other children are forced to be independent, i.e. without supervision. This is confirmed by her statement that such an attitude towards children has apparently been inherited from the time when a child's independence was a prerequisite to family survival. Such a method of upbringing is typical of nomadic nations and corresponds to having a way of life in difficult conditions on the fringes of civilization. The status of the oldest sister in Roma families is significant; she does almost everything for others and therefore does not have enough time for herself. The fact that boys are not raised to be independent and self-sufficient for a prolonged period of time was confirmed in Orechovdvor as well. All the Roma women said their sons did not do anything at home; at the age of 14 or 15 they might take out the rubbish, but they are not expected to do any other housework. Girls start helping at home with basic housework when they are 10 or 11 years old. Only the eldest daughter is obligated to take care of her younger siblings. Girls (women) only start to take care of the household fully after marriage, which, in the case of Roma girls, is as soon as they are 15 when they enter the so-called "world of adults". As mentioned in the previous subsection, the transition to this world is eased by intense assistance from her mother-in-law and grandmother.

As far as family education is concerned, Sekyt (1998) states that part of European family education is education towards being able to delay gratification (such as when you complete your school duties, when you can ride your bicycle). This ability to postpone pleasure is the foundation of discipline and self-discipline. It has always been attributed to those groups of people who live in prosperity; people who suffer deprivation use every opportunity to achieve pleasure and enjoyment (typical for economically weak Roma families). This does not, however, develop will-power but only worsens the possibility of achieving something that requires self-denial.

Another distinct tendency in Roma education is the relationship with independence. It is highly valued in European culture. Independence from others, knowing how to help oneself, not asking other people for help, and strengthening a child's selfconfidence is considered positive. Roma children are never alone; they are always surrounded by people close to them who can help them with everything. Decision-making is collective; everyone, including children, can take part in the decision-making process, but decision-making is communal, and the joint decision will be accepted by everyone. Family members do not subordinate themselves to it; they identify with the decision. 
For people who base all their considerations, decisions and actions on individuality it is difficult to imagine that other people can perceive themselves as part of a whole that is autonomous. Education in Roma families usually does not lead to individuality, so there is no room for education towards independence. Solidarity with all who belong to the family and family bonds is self-evident. Family is a source of security and a guarantee of needs being met, especially of needs linked with mental and emotional processes (Sekyt, 1998).

Balabánová (2000) states that the lifestyle of Roma families leads to the loss of responsibility for one's life; this is in contradiction with feeling responsible for oneself, which is the guiding principle of European culture. In Roma families of second and third societies, there is a predominance of spontaneity over purposeful activity, underestimation of independent practical activity of the child, weak communication (little communication, a simple language code), misconception of legitimate needs and age characteristics of the child (Fliegel, 1992). It is characterized by great emotionality and, at the same time, by inability of the parents to teach their children anything other than what is necessary for survival; everything else is considered unnecessary. According to Vágnerová (1999), relatively free, non-directive education, excessive free time and a minimal number of duties lead to Roma children not being taught to respect the norms of the wider population, and at school or later in their work, their behaviour may seem disturbing.

Fairy tales that mix old-fashioned themes from Indian fables with themes from the present lives of the Roma are an important component of functional family education. As is the case in other ethnicities, they affect the Roma children's subconscious and also contribute to the structuring of their consciousness. They perceive the stories literally, dive into them, and believe in their veracity. These fairy tales then affect the lives of Roma children more than school and media. It is even more important that many fairy tales are based on how Roma have won over gadzo due to their intelligence and cunning.

Tomová (1995) writes that Roma children do not experience adolescence in the usual sense, i.e. as a period of personality development. This is also confirmed by Klíma (1988), who stated that Roma people accept their children's personality as it is during adolescence, when children should in fact be discovering a need for change and active development of their own identity. This is not the case with Roma adolescents; their identity does not contain any ideal that would be contrary to their current self-image and serve as a model. Their approach is similar to the level of realism of a younger pupil, when self-image is passively accepted as a given. Focusing on the present makes building one's own identity unnecessary. Pubescent boys accept what comes; they do not think about themselves, and do not aspire to change their future actively. In this respect, we talk about a lack of self-reflection. 
A similar opinion about Roma adolescence is articulated by Dubayová (2001). It is a cultural and social phenomenon with a persistent and archaic cycle. In other words, childhood transitions directly into adulthood with all its consequences - predominantly in the sphere of family life. A period of adolescence, which has a significant socialization role in the life of a person in addition to biological maturation of personality, is omitted in many Roma groups. Simply put, the group does not provide time for young people to acquire qualifications, and thus to become economically independent.

A lack of introspection also results in the inability to feel empathy, deeper perception and understanding of another person. Klíma (1988) relates this to a prevailing pragmatism or even concretism - a fixation on concrete visible manifestations of the outside world. In social relationships, these characteristics of the personality of a Roma child are manifested by a more visible extroversion and easy networking, although these contacts are less differentiated and lack deeper intensity.

Tomová (1995) also notes that the openly aggressive behaviour of boys is tolerated in a large number of Roma families and often may even be targeted at their sisters. The requirements of girls and women are considerably stricter than for men. They have more obligations and responsibilities. They are guarded so that they do not meet with members of other ethnic groups. Securing food and maintaining the household is their duty. Their purity is guarded.

Žáková (1976) lists the following specifics of the educational influence of the Roma family on the child:

- More often than in non-Roma families, we notice a variation between strictness in education and tolerance of bad habits.

- A relatively small number of Roma children admit to the desire to escape from home, which is about a third compared with non-Roma children; this might be caused by greater freedom; two thirds of Roma children are convinced that their fathers are strong and brave, but at the same time they admit that they are sometimes ashamed of them (because of what they do, but not for instance, that they were in prison, on the contrary, sometimes they brag about this fact).

- While most children in mainstream society never report being ashamed of their mothers, Roma children state this in $33 \%$ of cases; family harmony and dependability of the family do not seem as strong as it is generally assumed.

- About $3 / 5$ of Roma children think that other children have a happier family life; it seems to them that family members do not like each other very much.

- Fear of physical punishment is twice as high as that of non-Roma children.

- If day-to-day contact with a child is interrupted (for example by being placed in a children's home), there is a significant alienation of parents from the child. 
Viková (1996) studied some psychological aspects of Slovak Roma families living in Prague and found the following results:

- In Roma families, children are more oriented towards their siblings than children in non-Roma families (they give more competencies to their siblings and have a more positive relationship with them).

- There are more intensive family ties for example between children and parents.

- The relationships of Roma parents to children are more differentiated and they openly prefer a certain child (which is clearly accepted by other children).

- Occurrences of sibling rivalry are fewer.

- They are less oriented towards family success; there is more freedom in the management of children (especially of boys; girls are led towards home-making activities).

- In both groups the mother is the closest figure to the child, but in Roma families this difference is not as distinctive as in non-Roma families (relations between Roma children and their fathers are more intense).

- In terms of the orientation of the nuclear family towards relatives, Roma families are more patrilocal, and non-Roma families are more matrilocal.

Demeterová (1998) also points out that there is a lack of discipline in Roma families they eat when they are hungry, get up and go to bed as needed. There is no definition of personal boundaries and personal affairs (Klíma, 1997). Among the Roma, everything is distributed naturally (they do not say please and thank you). This kind of upbringing leads to environmentally conditioned sociopathy rather than neuroticism. Roma children do not demonstrate neurotic features, as these result from exaggerated demands of the parents on the performance of the child, especially at school. These demands are not very common in Roma families.

Říčan (1998) states there are records of child abuse in Roma families (which was a complete rarity in the past) and neglect due to alcohol and drug addiction, as well as incest, which, according to Roma experts, was a taboo in recent Roma history. 


\section{Picture 2}

\section{Children at play}

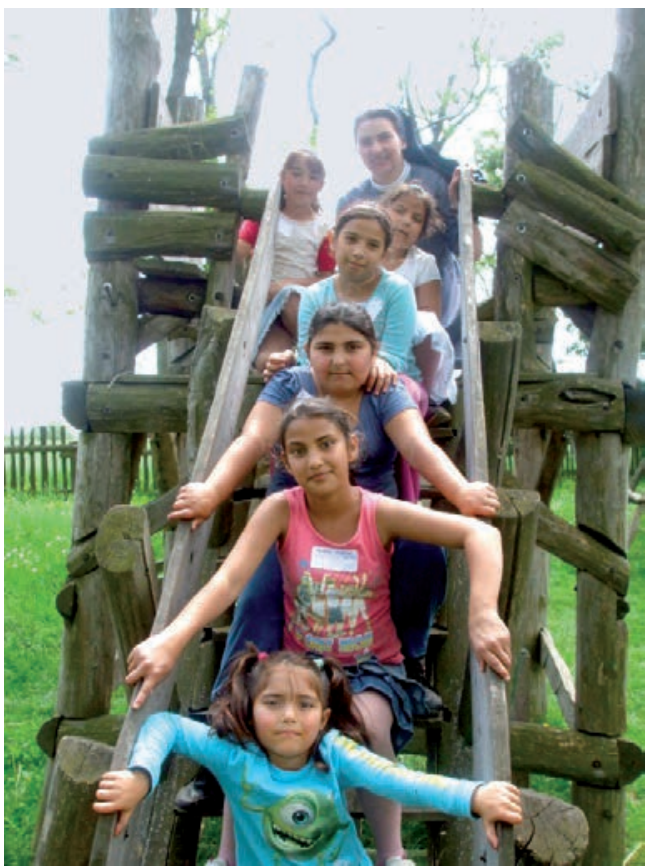

To acquaint a wider community to the notion of child rearing in Roma families, we introduce the ideas of Cipra (2001), who talks about social inheritance. Besides the maternal womb as a biological site or wrapping for the human embryo, there is also the social environment, which functions as the social womb of a small child, still an immature person, a sort of human larva. It represents a new stage of human metamorphosis and everything that surrounds this human larva, in the midst of which it experiences its childhood which it absorbs naturally, whether this is good or bad. It determines with what equipment the individual enters into the next stage of maturation, approaching the process of other metamorphoses leading to the peak of maturity.

From 1998-2000, within the framework of the project "Supporting the optimal development of children from a disadvantaged socio-cultural environment", the Faculty of Social Sciences of Masaryk University in Brno, supported by the British foundation Know How Fund, conducted research aimed at intense qualitative monitoring of the attitudes of mothers to children in Roma families and of families from a disadvantaged sociocultural environment in the wider population. The results showed different educational 
strategies in Roma and families from the wider population. Mothers of Roma children are mainly focused on the actual needs of children. They are particularly interested in how children feel, what they want and what they do not want. The immediate satisfaction of children is crucial, so they focus primarily on caring for them and meeting their needs. Mothers from the wider, general population mainly try to educate their children. They deal with the motives and characters of their children, develop strategies, rules, rewards and punishments so that children accept the values that parents hold and behave according to their ideas even in their absence (Navrátil, 2003).

Roma childhood is generally short. 13-year-old girls and 15-year-old boys are considered ready for marriage. It is almost unthinkable that a person would not marry. A young man can enter the circle of men only after marriage; women strive for marriage (Lužica, 2004).

\section{References}

Balabánová, H. (1999). Romské děti v systému českého základního školství a jejich následná profesionální príprava a uplatnění. In Romové v České republice (1945-1998). Praha: Socioklub. Sešity pro sociální politiku.

Cipro, M. (2001). Úvaha o výchově sociálně handicapovaných skupin. In Balvín, J. \& Tancoš, J. Romové a sociální pedagogika: 18. setkání Hnutí R v Přerově a Levoči, 7.-9. června 2001. Ústí nad Labem: Hnutí R.

Demeterová, H. (1998). Jak byli stvoření Romové. In Manuš, E. Jdeme dlouhou cestou. Praha: Arbor Vitae.

Dubayová, M. (2001). Rómovia v procesoch kultúrnej zmeny. Prešov: PU.

Fliegel, L. (1992). Výchova a vzdelávanie rómskych detí v školskom systéme. In Mann, A. B. Neznámi Rómovia. Bratislava: Ister Science Press.

Hamarová J. \& Holkovič, L'. (1987). Rodina, spoločnost', výchova. Bratislava: Veda.

Klíma, P. (1988). Poznámky k vývoji, výchově a vzdělávaní romského dítěte. In Vágnerová, M., Šturma, J., \& Klíma, P. Patopsychologie dítěte pro speciální pedagogy (2. přeprac. vyd., v SPN 1. vyd). Praha: Státní pedagogické nakladatelství.

Liégeois, J. P. (1995). Rómovia, Cigáni, Kočovníci. Bratislava: Charis.

Lužica, R. (2004). Rómska rodina. In Levická, J. Sociálna práca s rodinou. Trnava: Mosty a Trnavská univerzita.

Lužica, R. (2004). Kapitoly z rómskej kultúry. Bratislava: Slovak Academic Press.

Mann, A. B. (1992). Neznámi Rómovia. Bratislava: Ister Science Press.

Mann, A. B. (2000). Rómsky dejepis. Bratislava: Kalligram, s. r. o.

Matulay, S. (2000). Rómske etnikum. In Poláková, E. Rómovia včera dnes a zajtra. Zborník z konferencie Spišská Nová Ves. Nitra: UKF.

Navrátil, P. (2003). Romové v české společnosti. Praha: Portál.

Pocklanová, Z. (1992). Zo sekcie starostlivosti o deti z rómskych rodín. In Na pomoc učitelom rómskych žiakov. Bratislava: Ústav informácií a prognóz školstva, mládeže a telovýchovy.

Potočárová, M. (2008). Pedagogika rodiny. Bratislava: UK.

Říčan, P. (1998). S Romy žít budeme - jde o to jak. Praha: Portál.

Říčan, P. (2004). Cesta životem. Praha: Portál.

Sekyt, V. (1998). Odlišnosti mentality Romů a původ těchto odlišností. In Šišková, T. (Ed.). Výchova k toleranci a proti rasizmu. Praha: Portál. 
Sumec M. (2005). Medzigeneračné vzt'ahy v súčasnej rodinnej kultúre. Rodina a zodpovedné rodičovstvo dnes, 9.

Šarvajcová, M. (2015). Chudoba mladých ludí ako celospoločenský problém. Nitra: UKF.

Tomova, I. (1995). The Gypsies in the Transition Period. Sofia: International Center for Minority Studies and Intercutural Relations.

Vágnerová, M. (1999). Psychopatologie pro pomáhající profese. Praha: Portál.

Viková, L. (1996). Romská rodina z pohledu dětí ve věku 9-10 let. In Romano Džaniben, 3(1-2).

Žáková, H. (1976). Některé poznatky z výzkumu sociální adaptace a príčin psychické retardace cikánských dètí. Ústí nad Labem: Ústav školských informací při MŠ ČSR.

\section{Contact:}

PaedDr. PhDr. Denisa Selická, PhD.

Katedra sociológie, Filozofická fakulta

Univerzita Konštantína Filozofa

B. Slančíkovej, 94901 Nitra

Slovak Republic

E-mail: dselicka@ukf.sk

PaedDr. PhDr. Denisa Selická, PhD., works at the Department of Sociology at the UKF in Nitra as an assistant professor. She teaches the pedagogical disciplines of sociology of education, social pedagogy, and social policy. In her scientific and research activities she explores intergenerational relationships within the family. She is the author of monographs, academic textbooks and scientific studies. She is a member of Sociological Society at SAV in Bratislava and a member of Editorial Board of Youth and Society. 